\title{
PROSPECTS OF CORPORATE SOCIAL RESPONSIBILITY DEVELOPMENT IN THE EU IN SUSTAINABLE DEVELOPMENT
}

\author{
Oksana Safonchyk ${ }^{1}$, Konstiantyn Vitman ${ }^{2}$
}

\begin{abstract}
In the world practice, corporate social responsibility (CSR) is recognized an important component of sustainable development strategy, for which reason governments of many countries pay considerable attention to the promotion of CSR ideas at the national level, creating favourable conditions for socially responsible behaviour of national and foreign enterprises. The author aims to analyse the experience of regulation of corporate social responsibility policy in the EU Member States, to show the practice of national governments of the EU Member States in the field of CSR, and to determine prospects of corporate social responsibility at the modern development stage in view of implementing the concept of sustainable development. Summarizing approaches to the definition of CSR, it can be emphasized that CSR should positively influence society, in which the enterprise operates. It is a free choice in favour of increasing the welfare and moral and ethical values of society through appropriate approaches to doing business. Relations between enterprises both in the European Union and in other countries are increasingly based on the principles of CSR. Compliance with these principles becomes an important prerequisite for attracting foreign investment and obtaining government orders. In the international context, CSR is an efficient instrument to develop partnership and cooperation of countries in the context of achieving the Millennium Development Goals, to control the negative influence of the industrial sector on ecology, to prevent social crises, as a consequence, to ensure sustainable development of the world civilisation. Among the European institutions, the European Commission's committees play a key role in disseminating the idea of CSR. One of the main factors in strengthening the EU economy is considered precisely the stable growth based on the rational use of resources, ecology, and competition. Plans of the Strategy for 2012-2015-2020 clearly show that the European Union intends to strengthen control over economic management and "voluntarily oblige" the business to follow the rules of CSR. The goal of a new CSR Strategy is to create conditions favourable for sustainable development, responsible business conduct, and permanent employment in the medium and long term. Key changes in comparison with the policy for 2010 - definition of corporate social responsibility as "Responsibility of enterprises for their impact on society" and rejection of the principle of voluntariness: "the European Commission recognizes that some regulations stimulate CSR, therefore, public authorities should support the CSR development by applying a mix of voluntary and regulatory policies". As the study showed, the governments of the EU countries are actively engaged in the development and promotion of corporate social responsibility. The role of the state is manifested in the implementation of the following key functions: the state as a legislator and a controlling authority; the state as an employer; the state as a consumer and a buyer; the state as a partner; the state as an institutional investor; the state as a participant in international relations. The most significant results have been achieved by those EU Member States that use the systemic approach to CSR development. In these countries, responsible state structures have been formed that coordinate work in all areas. The approach to the choice of instruments is individual and is selected taking into account the priorities of the country's socio-economic development and the importance of economic, environmental, and social aspects. An example of Great Britain, France, Belgium, Estonia, and Spain shows the possibility of successful CSR development.
\end{abstract}

Key words: corporate social responsibility (CSR), sustainable development, social policy of government, state regulation, EU policy, Europe 2020 strategy, social strategy, CSR instruments.

JEL Classification: M14, J24, D30, H70

\footnotetext{
Corresponding author:

${ }^{1}$ National University "Odesa Law Academy", Ukraine.

E-mail: safonchyk.oksana@gmail.com

${ }^{2}$ Graduate School of Public Service

Training Centre for Masters of Public Administration and Professional Judges

National University "Odessa Academy of Law", Ukraine.

E-mail: knwittman@gmail.com
} 


\section{Introduction}

In the world practice, corporate social responsibility (CSR) is recognized an important component of sustainable development strategy, for which reason governments of many countries pay considerable attention to the promotion of CSRideas at the national level, creating favourable conditions for socially responsible behaviour of national and foreign enterprises. The introduction of CSR principles in constant business practices creates new opportunities and benefits for the country's socioeconomic development, including for the competitiveness of the economy, investment attractiveness, the fight against corruption, environmental and regional development, as well as strengthening social capital and information activities of the state and companies.

Corporate social responsibility has become widespread in the European Union, where companies incur voluntary obligations in the field of labour protection, waste management, business ethics while specifying similar requirements to their foreign units and partners. Implementation of international quality standards and environmental safety management in business activity became a mandatory condition for the exit and work in the European market (Shevchenko, 2014).

The issue of CSR has become the subject of numerous foreign studies. Modern scientific research is preceded by fundamental works on social responsibility of business in the second half of the XX century by such authors as H. Bowen (1953), K. Davis (1960), M. Friedman (1970), A. Carroll (1979), E. Freeman, who, in turn, rely on classical ideas put forward by P. Joule, J. Locke, A. Smith, M. Weber, T. Parsons, and others. Today, the CSR theme is distinguished as a separate interdisciplinary scientific direction. Attempts to study the area of social responsibility development within companies and at the level of government regulation have been made by T. Hoskins (2007), D. Detomasi (2005), A. Crane, D. Matten, J. C. Moon (2008) in their recent works, focused on defining the role of CSR in the international development and ways of implementing it, depending on the existing legislative framework, on the example of countries of the European Union.

The author aims to analyse the experience of regulation of corporate social responsibility policy in the EU Member States, to show the practice of national governments of the EU Member States in the field of CSR, and to determine prospects of corporate social responsibility at the modern development stage in view of implementing the concept of sustainable development.

\section{The methodology of research}

\subsection{The emergence \\ of the concept of a paradigm}

The birth of corporate responsibility took place in the United States of America. Since the XVII century, social philanthropy was an important component of American society, but by the fifties of the XX century, this activity was conducted by individuals, not companies. Legal boundaries and unwritten rules restricted the participation of business companies in public life (Abramov, 2005). During the 60 s and 70 s of the twentieth century, corporate philanthropy was recognized as a separate component of companies' activities. This period was characterized by charitable contributions that were aimed at improving the general state of social development of society. Including: donations to universities, local hospitals, cultural institutions, and support for other socially useful affairs. This activity contributed to the creation of the first corporate funds of companies. The distinction of this stage was the disinterestedness of philanthropy, without the economic benefits for the company (Kulyeshova, 2013).

With the beginning of the $80 \mathrm{~s}$, the views on philanthropy have changed a little. At this stage, the first attempts have been made to combine two opposing public views on corporate social philanthropy, in particular, its relationship with the company's overall goals. The key events of this period were the reduction of the influence of the authorities and the transfer of private power to the private sector within the policy of Ronald Reagan, who was elected president of the United States in 1980-1988.

Companies with headquarters in the USA, Canada, and Western Europe began to actively develop corporate philanthropy programs in Eastern Europe, Africa, Asia, the Pacific, etc. The experience of these companies has shown that there is a close relationship between economic growth and the development of human potential, social protection, environmental sustainability, as well as a stable and productive business environment (Sardak, Haslenko, 2017).

At the beginning of 2000, an important argument was put forward in favour of a new approach to corporate social responsibility. It testified that the economic and social goals of companies do not conflict but combine. Many economic investments benefit society, and many social investments are profitable economically.

In the modern world, socially responsible business activity is a generally accepted rule, which is followed by a lot of large, medium, and even small companies around the world. Given the extraordinary social and economic benefits that the social responsibility of business include, the issues of its development are of particular importance to the public authorities of many countries in the world and leading international organizations. The manifestation of this is the development of CSR standards and measures to promote the business to carry out socially responsible activities (Vorobee, 2005).

In most EU countries, state programs for supporting and promoting CSR have been developed and implemented in different forms. Due to these programs, the state determines the desired behaviour for business, engages companies of the private and public sectors 
in the joint fulfilment of socially important tasks, and materially stimulates business to socially responsible activities, etc.

\subsection{The genesis of the social responsibility concept}

In scientific literature, social responsibility is considered as a practice of responsible business that benefits both business and society and favours social, economic, and environmental sustainable development through the maximization of the positive influence of business on society and minimization of the negative one (Kotler, 2005).

According to other definitions, social responsibility of business means the achievement of commercial success by ways appreciating the moral and ethical principles of community and environment (Mazurenko, 2011).

Social responsibility of business can be also defined as a free choice of a company in favour of increasing the welfare of society due to relevant approaches to doing business and providing corporate resources. In the general sense, corporate social responsibility is all the company's actions that have a positive impact on society (Faydor, 2008).

In a broader sense, social responsibility should mean the responsible attitude of any company towards its product or service, consumers, employees, partners, an active social position of the company, which is harmonious coexistence, interaction and constant dialogue with the society, participation in solving the most acute social problems (Baffett, 2008).

So, for today, there is no single scientific approach to the interpretation of the category of "social responsibility of business". That is why, in our opinion, it is advisable to agree with the scientific approach (Fursa, 2012), in which it is noted that the fundamental principle of studying the phenomenon of social responsibility should be the understanding of it as a form of comprehension by the subject of its social essence and conscious activity, which is adequate to this. Various approaches to the definition of CSR are presented in Table 1 .

According to European practice, CSR covers seven main areas (Khamidova, 2017): respect for human rights; compliance with legislative requirements; business and corporate ethics; environmental protection; cooperation with stakeholders: employees, consumers, shareholders, community, business entities; compliance with international standards of conduct; transparency and accountability.

Summarizing approaches to the definition of CSR, it can be emphasized that CSR should positively influence society, in which the enterprise operates. It is a free choice in favour of increasing the welfare and moral and ethical values of society through appropriate approaches to doing business.

\section{Results and discussion}

\subsection{The main theoretical results of the study}

Relations between enterprises both in the European Union and in other countries are increasingly based on the principles of CSR. Compliance with these principles becomes an important prerequisite for attracting foreign investment and obtaining government orders.

In the international context, CSR is an efficient instrument to develop partnership and cooperation of countries in the context of achieving the Millennium Development Goals, to control the negative influence of the industrial sector on ecology, to prevent social crises, as a consequence, to ensure sustainable development of the world civilisation. Among the European institutions, the European Commission's committees play a key role in disseminating the idea of CSR.

The promotion of CSR principles in Europe began with the creation in 1995 of the European Business Network (CSR Europe), which was engaged in the dissemination and promotion of the principles of CSR. Officially, the CSR principles were presented at the European Summit in Lisbon in March 2000. According to heads of EU states, using the CSR mechanism "will transform the EU economy into the most competitive and dynamic in the world, which will be characterized by economic growth, increasing the number and quality of jobs, and great social cohesion" (Kulyeshova, 2013).

As experience shows, EU governments are active in promoting CSR. The main document of these countries is Green Paper, adopted in 2001, which presents a European framework for CSR, according to which the

Table 1

Approaches to the definition of corporate social responsibility

\begin{tabular}{|l|l|}
\hline \multicolumn{1}{|c|}{$\begin{array}{c}\text { Countries using different } \\
\text { approaches }\end{array}$} & \multicolumn{1}{c|}{ Essential characteristics of an approach } \\
\hline USA & Volunteer programs for company workers and charity (Vorobee, 2005) \\
\hline European countries & Doing business in a socially responsible manner (Lazorenko, Kolyshko, 2008) \\
\hline $\begin{array}{l}\text { World Business Council for } \\
\text { Sustainable Development }\end{array}$ & $\begin{array}{l}\text { The long-term commitment of companies to behave ethically and promote economic development while } \\
\text { improving the quality of life of workers and their families, communities, and society in general (Lazorenko, } \\
\text { Kolyshko, 2008) }\end{array}$ \\
\hline Responsible Business Forum & $\begin{array}{l}\text { The responsible attitude of any company to its product or service, to consumers, employees, partners; the } \\
\text { active social position of the company, consisting of harmonious coexistence, interaction, and constant } \\
\text { dialogue with the society, participation in solving the most acute social problems (Berezina, 2010) }\end{array}$ \\
\hline
\end{tabular}


government is developing a national policy, including mechanisms and tools to support best practices and innovative ideas. In addition to this, documents were developed, which the European Union countries use for the development of national CSR policies. They include (Shevchenko, 2014):

- EU Environmental Action Plan, which sets the main directions of activity of the states of the European Union in the field of environmental protection;

- Integrated Product Policy (IPP), designed to monitor the extent of the environmental impact of production processes and stimulate the introduction of the most effective methods of production;

- Eco-Management and Audit Scheme (EMAS), which recommends a system of assessment and reporting on CSR and aims to introduce environmentally friendly management in the company;

- European Eco-Efficiency Initiative (EEEI), developed by the World Business Council for Sustainable Development, the European Partners for the Environment, and the European Commission, aims to integrate the principles of environmental performance into industrial and economic strategic plans of companies; - Resolution of the European Parliament "EU standards for European Enterprises operating in developing countries: towards a European Code of Conduct" proposes the creation of a European model corporate code of conduct;

- Europe 2020 strategy: a strategy for smart, sustainable, and inclusive growth" (adopted on October 25, 2011), which presents new directions for CSR development in the EU (Shevchenko, 2014).

One of the main factors in strengthening the EU economy is considered precisely the stable growth based on the rational use of resources, ecology, and competition. Plans of the Strategy for 2012-20152020 clearly indicate that the European Union intends to strengthen control over economic management and "voluntarily oblige" the business to follow the rules of CSR. The goal of a new CSR Strategy is to create conditions favourable for sustainable development, responsible business conduct, and permanent employment in the medium and long term. Key changes in comparison with the policy for 2015 - definition of corporate social responsibility as "Responsibility of enterprises for their impact on society" and rejection of the principle of voluntariness: "the European Commission recognizes that some regulations stimulate CSR, therefore, public authorities should support the CSR development by applying a mix of voluntary and regulatory policies" (Social Corporate, 2015).

\subsection{Formation of the conceptual foundations of the model}

The basic postulate of state regulation of any socioeconomic phenomenon is the application of it only in the event that the market mechanism is unable to solve such a task. State regulation of CSR should be carried out with varying intensity in accordance with the stage of the economic cycle and the effectiveness of market regulation.

At the same time, different priorities of state regulation of CSR should be established (Figure 1).

Consequently, CSR at different stages becomes different in nature and significance. It is able to change under the influence of factors of market and state regulation. Their reasonable combination in accordance with the stage of the economic cycle and the depth of social problems of society is necessary.

Today, the main task of a business is to find a "golden mean" between its economic and social goals and try to combine them so that, through greater economic achievements, they promote the development of social programs.

An illustrative example of the active role of the state in promoting CSR is Great Britain, which has achieved significant results in this area. The latter is associated, first

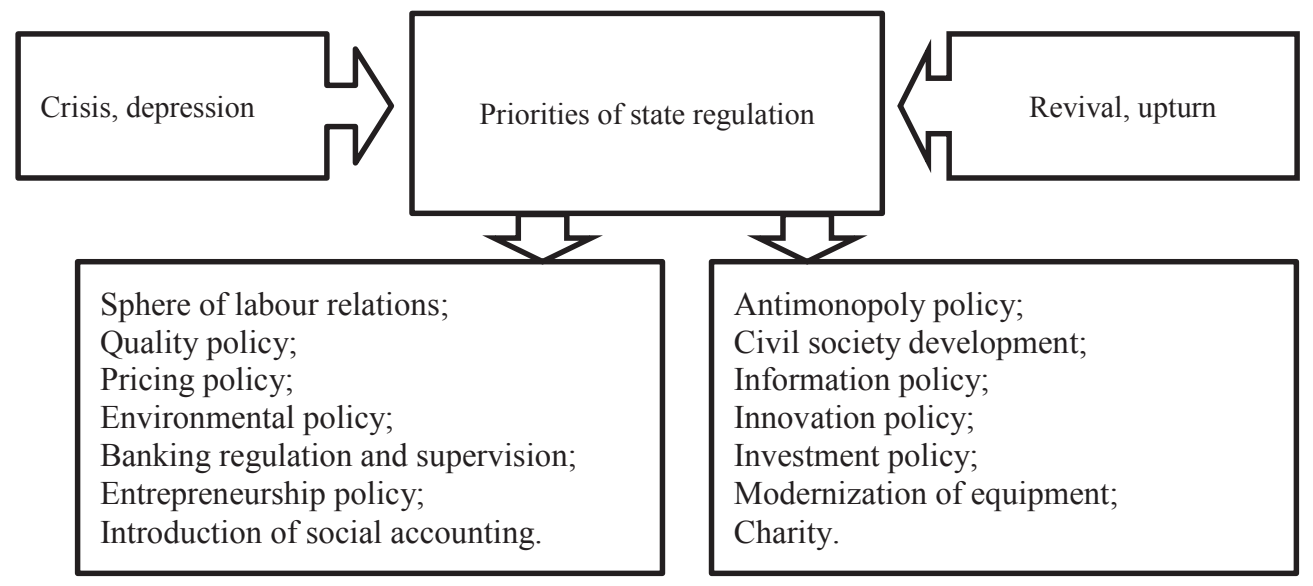

Figure 1. Priorities of state regulation of CSR in the context of sustainable development

Source: (Vorona, 2010; Kulyeshova, 2013) 
of all, with the fact that CSR has become an independent sphere of government that is coordinated by the central government. Since 2001, the post of Corporate Social Responsibility Minister has been established in Great Britain, state resources have been allocated for the creation of CSR Academy and the preparation of information and methodological support; more than 12 ministries and departments are involved in promoting CSR at the sectoral level, using various tools of motivation and stimulation (Bodnaruk, 2016).

Among the areas of British CSR policy are: support for innovative approaches and demonstrative practices of stakeholders and companies; definition of a minimum level of CSR, for example, on such fundamental issues as healthcare, safety, and equal opportunities; business support that brings social and environmental benefits to society. The government participates in many international projects, develops financial mechanisms and incentives, implements CSR in the public procurement system, creates programs for increasing the transparency of a number of sectors of the economy, expands the scope of corporate reporting, standardizes the contribution of companies to sustainable development, creates reputational incentives, stimulates the public dialogue with CSR, as well as applies various measures to promote CSR, including by using the authority of political leaders and Internet resources.

It is important to mention the Companies Act 2006, which introduced regular reporting - Business Review that requires companies to disclose general information on environmental issues, employee relations policies, and interaction with the local community (Bodnaruk, 2016).

Almost at the same time, parliament has adopted tax incentives for investments in the social sphere. The Community Investment Tax Relief (CITR) encourages private investment through the Community Development Finance Institutions (CDFIs) as nonprofit and profit institutions that are located in disadvantaged regions and are in difficult financial situations. In accordance with certain conditions, CITR is designed for both individuals and legal entities, offering to invest by way of loan-purchase of securities or share participation in institutions accredited by the CDFI.

Incentives (up to $25 \%$ ) depend on the volume of investments and reduce the income tax for investors and corporate tax liabilities. In addition to the CITR, the government also proposes tax incentives to encourage corporate support for money, equipment, and other material assistance to volunteers and local communities, including remittances to the wage bill and gift aid. Equally important are additional initiatives of the British government. They include measures for the implementation of international and national standards, such as ISO 14001 and BS 8555, the development in 2006 of the world's first sustainable management standard, BS 8900, which determines the results of sustainability of organizations that they must achieve and which are the main measure of their progress, issue of the "Environmental Reporting Guidelines", etc. (Social Corporate, 2015).

The Belgian government takes an active role and favours the promotion of CSR. Belgium has adopted special legislation on regulation and promotion of CSR. Within the framework of the Federal Coordinating Policy on Sustainable Development, the government has prepared a document entitled "Recommendation Basis: Corporate Social Responsibility in Belgium", which is the basis for CSR for government agencies, businesses, and other participants (Social Corporate, 2015). Specific measures to implement the concept of CSR are formulated in the Federal CSR Plans. The State Commission for the Regulation of Banking, Financial and Insurance Services together with the Federation of Industrial Enterprises has prepared the Corporate Governance Code. Schemes of social and eco-labels have become widespread. The Belgian Social Label certified by the Belgian government confirms that the certified company adheres to the eight fundamental principles of the World Trade Organization Convention. The system of eco-labels, developed by the Brussels Institute of Natural Resources Management, demonstrates the application by certified companies of quality management systems, international standards that meet the requirements in the field of environmental protection. In order to promote and assist in the implementation of the CSR principles in practice, the Belgian government has opened two special information centres.

In France, the development and regulation of CSR have also been distinguished in a separate area of national and local government work. In this country, the development and regulation of CSR take place within the framework of the National Sustainable Development Strategy, which was adopted by the French Government in 2003 for 5 years and updated in 2006. The main direction of the strategy is the voluntary formation of CSR commitments by large businesses in the field of CSR through the work with industry associations of employers (commitments to improve carbon dioxide emissions, safety conditions, energy management and water consumption, waste management and access to innovation, and so on) (Shevchenko, 2014).

For Estonia, the concept of CSR is relatively new and is at the development stage. There is no special legislation. Many aspects of CSR are regulated by sectoral legislation - labour, trade, tax, and environmental protection. There are a number of environmental labels in Estonia, such as Clean Environment, Green Energy, Green Key, Certificate of Real and Interesting Estonia, Myald Mark, Human's Green Label, Eco, EU Ecolabel, Environmentally Friendly Product. For enterprises with some of these environmental certificates, the government of Estonia applies tax incentives. Enterprises are also exempted from paying taxes on gifts and donations to non-governmental organizations and funds that are 
included in the special list of exempted organizations. Each year, the state organizes a competition, in which the best companies in nominations "Best developer of modern technologies of the year", "The most important contribution to the development of society" are awarded certificates of honour and awards (Shevchenko, 2014; Bodnaruk, 2016).

In Spain, there is currently no special legislation on CSR but the issue of adopting a CSR law is on the government's agenda. Spain's sectoral legislation regulates many CSR issues such as: labour conditions, labour contracts, health and safety, rights of disabled people, consumer rights, environmental protection, and others. The Government of Spain has formally approved and recommended the use of the Guidelines for Multinational Enterprises developed by the Organization for Economic Cooperation and Development. The Ministry of Economics has an open information centre to provide consulting assistance for using the Guidance and collecting information about national experiences. The Spanish Association for Standardization and Certification (AENOR) is involved in developing international standards for corporate ethics and social management. Aragon's authorities (northeastern Spain) provide tax incentives to companies that make charitable assistance (Social Corporate, 2015).

\section{Research results. Integration of corporate social responsibility into management strategy}

By encouraging business, population, and civil society to socially responsible behaviour, the European Union uses a variety of incentive tools and incentives, from mild forms of regulation and motivation to strictly defined requirements of the law. Today the following areas of the European Union policy in the field of CSR are distinguished (The Basis of Business Philosophy, 2016; Bodnaruk, 2016; Shevchenko, 2014):

- Informing the public about the role of CSR in the development of society and the best practices of socially responsible business. European governments create special information centres, call the media for propaganda, discuss issues, inform the readers about the best national and foreign CSR practices.

- With the support of the government, brochures, reference materials on various aspects of CSR are published and conferences, forums, seminars, and round tables are held.

- Encouraging and supporting additional voluntary CSR business initiatives. In order to stimulate and promote the ethical conduct of CSR business, EU Member States are the initiators and take an active part in the development and implementation of sectoral and corporate codes of conduct, which establish the basic principles of ethical business conduct. One of the popular tools is the introduction of the mechanism of social and eco-labels.
- Training, research, and methodological support. The EU contributes to the large-scale growth of local CSR capacities: CSR workshops and trainings for civil servants, business representatives, members of public/ trade unions, which continue to serve as catalysts for CSR promotion, are practiced.

- Involving the parties concerned (stakeholders) in CSR issues. The development of this area of government policy involves facilitating dialogue and partnership between the state, the business community, professional and community associations, and other stakeholders in implementing CSR to consolidate resources and achieve more meaningful results. The opinion of stakeholders is always taken into account when developing the CSR development policy documents.

- International cooperation on CSR. The development of corporate social responsibility is an idea that has captured most countries in the world. In order to join forces and promote the international principles of CSR, governments in all ways support the initiatives of international organizations, in particular, the UN Global Compact Initiative, sign conventions, conclude agreements, and participate in international forums.

- In order to achieve the results, the EU promotes the development of a system of international standards of management, reporting indicators, CSR audit, stimulates the certification of products and enterprises in accordance with international standards, which, in turn, provides national companies with access to world markets, promotes the system of international social and environmental labelling to ensure equal rights of trade in different countries. Recently, socially responsible investment (SRI) is gaining in popularity, which is based on taking into account when making investment decisions the social and environmental consequences of investments.

- Implementation of CSR assessment and reporting systems. With the state support, the methodical guidance on reporting is being developed, and special structural units are created to assist in the preparation of non-financial reports. In some European countries, the inclusion of information on compliance with CSR in regular audit reports is mandatory. This is especially widely practiced in those industries whose activities can cause damage to the environment, for example, in the chemical or metallurgical industries.

- Use of tax and investment instruments. Creating favourable conditions in which socially responsible behaviour of companies is rewarded through the provision of tax incentives, preferences, and subsidies. Income from social expenditures, charitable donations, targeted deductions to non-profit organizations, and funds in most European countries are not taxed.

- Funds are not taxed in most European countries. The state is involved in co-financing of socially significant projects. The most important non-tax preference for socially responsible business is the inclusion of 
CSR in the selection of enterprises for the execution of state orders.

- Special CSR legislation. In some European countries, special legislation is created, which takes into account the abovementioned tools of stimulation and regulation of corporate social responsibility of enterprises.

The European Union has done enormous efforts to promote the principles of CSR in the business practice of strategic management. All EU Member States successfully apply CSR in solving the priority tasks of socio-economic development through the development of a National Agenda on Corporate Social Responsibility Standards. In the European Union countries, the powers of CSR implementation and management are delegated to a number of ministries and departments (Bodnaruk, 2016; Ramazanov, 2007).

\section{Conclusions}

In the economically developed countries of the world, since the 50s of the XX century, the concept of corporate social responsibility has become widespread, consisting in the conscious attitude of business entities to the requirements of social necessity, social tasks, moral and ethical norms and values, understanding of the consequences of their own activities for society, state, consumers, business partners, and employees. This concept has gained its development and definitive consolidation in the concept of sustainable development, which was formed in 2012 at the Rio Summit. In practice, corporate social responsibility involves business's compliance with the following principles: providing consumers with products and services of high quality; creating decent working conditions, timely payment of wages, investing in further professional development of employees; strict compliance with financial, labour, and environmental legislation; building good-faith and honest relationships with all partners; attention to social expectations of society and observance of generally accepted ethical norms in business practice; participation in the development of civil society through the implementation of partnership programs and projects aimed at the development of regions and local communities.
As the study showed, the governments of the EU countries are actively engaged in the development and promotion of corporate social responsibility. The role of the state is manifested in the implementation of the following key functions: the state as a legislator and a controlling authority; the state as an employer; the state as a consumer and a buyer; the state as a partner; the state as an institutional investor; the state as a participant in international relations. The most significant results have been achieved by those EU Member States that use the systemic approach to CSR development. In these countries, responsible state structures have been formed that coordinate activities in all areas. The approach to the choice of instruments is individual and is selected taking into account the priorities of the country's socio-economic development and the importance of economic, environmental, and social aspects. An example of Great Britain, France, Belgium, Estonia, and Spain shows the possibility of successful CSR development.

Consequently, at the modern stage, in order to step up processes in the area of social responsibility in Ukraine, first of all, it is necessary to (Reznyk, 2014): change the public consciousness in relation to understanding the meaning, significance of social responsibility for the development of a socially oriented state, and among the entrepreneurs themselves - the strategic importance of a socially responsible position for strengthening the competitiveness of companies in the market and long-term sustainable development; form a legislative framework that will ensure business interest in the implementation of social programs, as well as regulatory acts that stimulate the development of social responsibility; create an affiliate network, in which participants get wide opportunities for promoting corporate image at the regional and macroeconomic levels; introduce methodological bases of assistance in planning and implementation of specific social projects and programs, implementation of corporate social responsibility systems; create a data bank for social and environmental initiatives that could be implemented by public authorities, non-governmental organizations, and entrepreneurial structures.

\section{References:}

Abramov, R. (2005). Korporativnaya sotsialnaya otvetstvennost kak primer organizatsionnogo izomorfizma $\mathrm{v}$ usloviyakh globalizatsii [Corporate social responsibility as an example of organizational isomorphism in the context of globalization]. Zhurnal issledovaniy sotsialnoy politiki, 3, 327-346. (in Russian)

Analytics (2017). Social responsibility of business. Information and analytical material. Retrieved from: http://www.svb.org.ua

Baffett, U. (2008). Esse ob investitsiyakh, korporativnykh finansakh i upravlenii kompaniyami [Essay on investment, corporate finance and company management]. Moscow: Alpina Business Books. (in Russian)

Belyavska, K. S. (2011). Sotsialna vidpovidalnist biznesu: evolyutsiya pohlyadiv na problemu. [Social responsibility of business: the evolution of views on the problem]. Visnyk Khmelnytskoho natsionalnoho universytetu, 1, 228-334. (in Ukrainian)

Berezina, O. Yu. (2010). Suchasni modeli korporatyvnoyi sotsialnoyi vidpovidalnosti [Modern models of corporate social responsibility]. Ekonomichnyy prostir: zb. nauk. pr. Dnipropetrovsk: PDABA Economic Space: Sb. sciences Dnipropetrovsk, 41, 194-202. (in Ukrainian) 
Bodnaruk, O.(2016). Yevropeyskyy dosvid derzhavnoho rehulyuvannya korporatyvnoyisotsialnoyividpovidalnosti [European experience of state regulation of corporate social responsibility]. Visnyk DonDUU. Menedzher, 2(71), 41-48. (in Ukrainian)

Bowen, H. (1953). Social responsibilities of the businessman. N.-Y.: Harper \& Row.

Davis, K. (1960). Can business afford to ignore social responsibilities? California Management Review, 2, 17-21.

Detomasi, D. (2005). The Political Roots of Corporate Social Responsibility. Journal of Business Ethics, 82(4), 29-32.

Carroll, A. (1979). Three-dimensional conceptual model of corporate social responsibility performance. Academy of Management Review, 4, 5-9.

Crane, A., Matten, D., \& Moon, J. C. (2008). Theory Searching for a Political Home. Corporations and Citizenship. Cambridge: Cambridge University Press.

Government as Partner? (2006). CSR Policy in Europe. Gutersloh: Bertelsmann Stiftung.

Hoskins, T. (2007). Corporate Social Responsibility Handbook. London: The ICSA.

Faydor, M. (2008). Responsibility of business. Business world, 5, 66-69.

Fedorova, O. V. (2011). Sotsialna vidpovidalnist biznesu - chy mozhlyvyy tsey fenomen v Ukrayini? [Social responsibility of business - is this phenomenon possible in Ukraine?]. Ekonomika. Menedzhment. Pidpryyemnytstvo : zb. nauk. prats, 23(I). (in Ukrainian)

Friedman, M. (1970). The Social Responsibility of Business is to Increase its Profits. The New York Times. Magazine, September 13. Retrieved from: http: //www.colorado.edu/studentgroups

Freeman, R. (2004). Strategic management: a stakeholder Approach. Boston: MA: Pitman.

Fursa, M. (2012). Rozvytok korporatyvnoyi sotsialnoyi vidpovidalnosti v Ukrayini: derzhavno-upravlinskyy aspekt [Development of Corporate Social Responsibility in Ukraine: Public-Management Aspect]. Efektyvnist derzhavnoho upravlinnya, 30, 67-74. (in Ukrainian)

Kretova, A., \& Berezovska, N. (2011). Rozvytok korporatyvnoyi sotsialnoyi vidpovidalnosti v Ukrayini za uchasti derzhavy: mekhanizm vzayemodiyi [Development of corporate social responsibility in Ukraine with the participation of the state: the mechanism of interaction]. DonNUU - Donetsk: TECHNO-PAK. Volume XII. (in Ukrainian)

Kotler, P. (2005). Corporate Social Responsibility. How to do as much good as possible for your company and society. Kyiv: Standard.

Khamidova, A. (2017). Korporatyvna sotsialna vidpovidalnist yak faktor pidvyshchennya efektyvnosti mekhanizmu derzhavnoho rehulyuvannya ekonomiky [Corporate social responsibility as a factor of increasing the efficiency of the mechanism of state regulation of the economy]. Retrieved from: http://www.csrjournal.com/news/2661korporativna-socialna-vidpovidalnist-yak-faktor-pidvishhennya-efektivnosti-mexanizmu-derzhavnogoregulyuvannya-ekonomiki.html (in Ukrainian)

Kulyeshova, L. V. (2013). Korporatyvna sotsialna vidpovidalnist yak instrument staloho rozvytku pidpryyemstv [Corporate social responsibility as an instrument for sustainable development of enterprises]. Visnyk Donbaskoyi derzhavnoyi mashynobudivnoyi akademiyi, 1(30), 195-199. (in Ukrainian)

Lazorenko, O., \& Kolyshko, R. (2008). Bazova informatsiya z korporatyvnoyi sotsialnoyi vidpovidalnosti: posibnyk [Basic information on corporate social responsibility: a guide]. Kyiv: Energy. (in Ukrainian)

Mazurenko, V. P. (2011). Suchasna kontseptsiya korporatyvnoyi sotsialnoyi vidpovidalnosti u mizhnarodnomu biznesi [Contemporary Concept of corporate social responsibility in international business]. Efektyvna ekonomika. Retrieved from: http://www.economy.nayka.com.ua/?op=1\&z=1199 (in Ukrainian)

Melnyk, S. V., Tresvyatska, T. A., \& Budonna, L. V. (2010). Kontseptsiya reformuvannya vitchyznyanoyi systemy rehulyuvannya umov, hihiyeny, bezpeky ta okhorony pratsi [The concept of reforming the domestic system of regulation of conditions, hygiene, safety and occupational safety]. Luhansk: DU NDI STV. (in Ukrainian)

Michael Porter (2007). Theory of social responsibility. Financial Times. October 1, 2007. Retrieved from: http://blogs.ft.com/businessblog

Ramazanov, A. (2007). Kontseptsiya korporatyvnoyi sotsialnoyi vidpovidalnosti. Problemy teoriyi ta praktyky upravlinnya [Concept of corporate social responsibility. problems of the theory and practice of management]. Kyiv: Energy. (in Ukrainian)

Responding (2003). Responding to the Leadership Challenge: Findings of a CEO Survey on Global Corporate Citizenship. Geneva.

Reznyk, N. (2014). Sotsialna vidpovidalnist biznesu: sutnisno-teoretychni aspekty [Social responsibility of business: essentially theoretical aspects]. Zhurnal Yevropeyskoyi Ekonomiky. Veresen. (in Ukrainian)

Sardak, S. E., \& Haslenko, K. S. (2017). Vnutrishnya korporatyvna sotsialna vidpovidalnist pidpryyemstva: teoretychni ta praktychni aspekty [Internal corporate social responsibility of the enterprise: theoretical and practical aspects]. Retrieved from: http://economyandsociety.in.ua/journal/12_ukr/57.pdf (in Ukrainian)

Shevchenko, O. (2014). Regulation of the corporate social responsibility policy: the practice of the member states of the European Union. Actual problems of international relations. Release 122 (part I).

Social Corporate (2015). Social Corporate Responsibility in Belgium. Retrieved from: http://www.socialecon-omy.be/ ContentSite/MVORSE/publicatie_CSR_RefFramework.pdf 
Sofiyenko, A.V. (2012). Sotsialna vidpovidalnist biznesu: rozuminnya ta suchasni tendentsiyi. [Social responsibility of business: understanding and current trends]. Ekonomichni innovatsiyi, 47, 297-301. (in Ukrainian)

Stratehiya spryyannya (2012). Stratehiya spryyannya rozvytku sotsialnoyi vidpovidalnosti biznesu v Ukrayini [Strategy for Promoting the Development of Corporate Social Responsibility in Ukraine]. Retrieved from: http:/ /www.svb.org.ua/ sites/default/files/201309_strategiya_spriyannya_rozvitku_svb_v_ukrayini.pdf (in Ukrainian)

United Nations Global Compact. Retrieved from: http://www.unglobalcompact.org./participants/search

Vorobee, V. (2005). Corporate Social Responsibility or Benefit? Kyiv: Kyiv-Mohyla Business Studio, №10. Retrieved from: http://www.management.com.ua/cm/cm037

Vorona, O. (2010). Praktyka realizatsiyi sotsialnoyi vidpovidalnosti biznesu v Yevropi ta $v$ Ukrayini [Practice of realization of social responsibility of business in Europe and in Ukraine]. Retrieved from: http://www.rusnauka.com/ 10_NPE_2010/Economics/62028.doc.htm (in Ukrainian) 